which Mr. Preston calls in question, it would be manifestly illogical on his premisses for Mr. Crookes to regard the isolated molecule as a solid, even though, according to Mr. Preston, it may possibly possess certain properties in common with what we call solids, for solidity, according to Mr. Crookes, being "merely the effect on our senses of the motion of the discrete molecules among themselves," it would be exceedingly arbitrary to ascribe to the molecules themselves a quality which, as we commonly know it, is simply an effect of their motion.

July 3

$$
\text { E. Douglas Archibald }
$$

\section{Minerva Ornaments}

I NOTICE that a correspondent writing from America expresses his scepticism as to the figural character of certain stone objects in Dr. Scliliemann's collection at South Kensington. Judging from the analogy of similar objects found in America, he pronounces them to be "net-sinkers" and not idols. Whatever, however, may be the nature of the American objects, I think there can be but little doubt that Dr. Schliemann is right in considering the objects discovered by him at Hissarlik to be rude representations of a deity. At first sight they certainly have but little resemblance to anything of the sort, but a careful examination shows that several are marked with the rude delineation of a human face-or, as .Dr. Schliemann believes, of an owl's face -as well as of a triple necklace, and sometimes also the charac teristics of a woman. Occasionally the hair is represented on the back of the head by straight lines. The delineation is sometimes incised, sometimes painted, though the paint is mostly worn off. As the marked objects are of the same shape as the unmarked ones, we can have no hesitation in inferring that both were intended for the same purpose.

July 4

\section{Arthur Young's Travels in France}

A FEw months ago my friend Mr. F. F. Tuckett, of Bristol, drew my attention to a passage in Arthur Young's Travels in France, published in $\mathbf{1 7 9 2}$, narrating a visit to Lavoisier and to a certain M. Lomond, the inventor of an electric telegraph, which in some points anticipated that of Ronalds. The mention of Lomond's name in a historical list of telegraphic inventors recently published by your contemporary, the Scientific American, induces me to send you the inclosed extract as likely to be of interest to the readers of NATURE.

Univ. Coll., Bristol, June I8

"The r6th.-To M. Lavoisier by appointment. Madame Lavoisier, a lively, sensible, scientific lady, bad prepared a dêjeuné Anglois of tea and coffee, but her conversation on $\mathrm{Mr}$. Kirwan's Essay on Phlogiston, which she is translating from the English, and on other subjects which a woman of understanding, that works with her husband in his laboratory, knows how to adorn, was the best repast. That apartment, the operations of which have been rendered so interesting to the philosophical world, I had pleasure in viewing. In the apparatus for aërial experiments nothing makes so great a figure as the machine for burning inflammable and vital air, to make or deposit water; it is a splendid machine.

"Three vessels are held in suspension witb indexes for marking the immediate variations of their weights; two, that are as large as half-hogsheads, contain the one inflammable, the other the vital air, and a tube of communication passes to the third, where the two airs unite and burn; by contrivances, too complex to describe without plates, the loss of weight of the two airs, as indicated by their respective balances, equal at every moment to the gain in the third vessel from the formation or deposition of water, it not being yet ascertained whether the water be actually made or deposited. If accurate (of which I must confess I have little conception) it is a noble machine. Mons. Lavoisier, when the structure of it was commenced, said, 'Mais oui, monsieur, et même par un artiste François!' with an accent of voice that admitted their general inferiority to ours. It is well known that we have a considerable exportation of mathematical and other curious instruments to every part of Lurope, and to France among the rest. Nor is this new, for the apparatus with which the i rench Academicians measured a degree in the polar circle was made by Mr. George Graham. Another engine Mons. Lavoisier showed us was an electrical apparatus inclosed in a balicon, for trying electrical experiments in any sort of air. His pond of quicksilver is considerable, containing $250 \mathrm{lbs}$., and his water apparatus is great, but his furnace did not seem so well calculated for the higher degrees of heat as some others I have seen. I was glad to find this gentleman splendidly lodged and with every appearance of a man of considerable fortune. This ever gives one pleasure: the employments of a state can never be in better hands than of men who thus apply the superfluity of their wealth. From the use that is generally made of money, one would think it the assistance of all others of the least consequence in affecting any business truly useful to mankind, many of the great discoveries that, have enlarged the horizon of science having been in this respect the result of means seemingly inadequate to the end : the energetic exertions of ardent minds, bursting from obscurity, and breaking the bonds inflicted by poverty, perhaps by distress.

" To the 'Hotel des Invalids,' the major of which establishment had the goodness to show the whole of it. In the evening to Mons. Lounond, a very ingenious and inventive mechanic, who has made an improvement of the jenny for spinning cotton. Common machines are said to make too hard a thread for certain fabrics, but this forms it loose and spongy.

"In electricity he has made a remarkable discovery : you write two or three words on a paper, he takes it into a room and turns a machine inclosed in a cylindrical case, at the top of which is an electrometer, a fine small pith ball; a wire connects with a similar cylinder and electrometer in a distant apartment; and his wife, by remarking the corresponding motions of the ball, writes down the words they indicate: from which it appears he has found an alphabet of motions. As the length of the wire makes no difference in the effect, a correspondence might be carried on at a distance-within and without a besieged town, for instance, or for a purpose much more worthy, and a thousand times more harmless, between two lovers prohibited or prevented from any better connection.

"Whatever the use may be, the invention is beautiful. Mons. Lomond has many other curious machines, all the entire work of his own hands. Mechanical invention seems to be in him a natural propensity." ("Travels during the Years 1787,1788 , and I789," by Arthur Young, Esq., F.R.S. Vol, i. p. 64.)

\section{"Saxifraga umbrosa" adorned with Brilliant Colours by the Selection of Syrphidæ}

Among Diptera the most assiduous visitors of flowers are certain Syrphidæ, which, elegantly coloured themselves, are fond of splendid flower-colours, and, before eating pollen or sucking nectar, like to stop a while, hovering free in the air, in front of their favourites, apparently fascinated, or at least delighted, by the brilliancy of their colours. Thus I repeatedly observed Syrphus balteatus hovering before the flowers of Verbascum nigrum, often Melanostoma mellina, and Ascia podagrica before Veronica chamadrys; in the Alps the lank Sphegina clunipes before Saxifraga rotundifolia, and in my garden Ascia podagrica before Saxifraga umbrosa.

Of Verbascum nigrum the main fertilisers are humble-bees, Diptera co-operating only in a subordinate degree; in the case of the three other species, on the contrary, the above-named Syrphidæ are such frequent visitors and cross-fertilisers that we may safely conclude that it is by their selection of elegantlycoloured varieties that these flowers have acquired their beautiful peculiarity. Hence, in order to estimate the colour-sense of these Syrphidæ, it is worth while to consider what colour-combinations they have been able to produce by their selection.

Saxifraga umbrosa being, as far as hitherto known, their finest masterpiece, we may in the first place look at the variegated decoration of this species. Its snow-white petals are adorned with coloured spots, which in size and intensity of light gradually decrease from the base of the petals towards their extremity. Indeed, nearest to their base, within the first third of their lengtb, there is a large irregular spot of an intense yellow; about the middle of their length there follows a narrower cross band of red colour, vermilion towards the base, intensely pink towards the outside, not reaching the margins of the petals, sometimes dissolved into several separate spots; lastly, beyond the middle of the length of the petals there are three to eight smaller roundish spots of a paler violet-pink colour.

The flowers of Veronica chamadrys prove that also gay blue colours are perceived and selected by Ascia.

Lippstadt, Germany 